\title{
THE SUBDIVISION OF FICUS SUBGENUS PHARMACOSYCEA SECTION PHARMACOSYCEA (MORACEAE)
}

\author{
C.C. BERG \\ Bergen Museum, University of Bergen, Allégate 41, 5007 Bergen, Norway; \\ Nationaal Herbarium Nederland, Universiteit Leiden branch, \\ P.O. Box 9514, 2300 RA Leiden, The Netherlands
}

\section{SUMMARY}

The two subsections of Ficus sect. Pharmacosycea, subsect. Bergianae and subsect. Petenenses, are supplementary described and discussed.

Key words: Ficus sect. Pharmacosycea, subsections, Neotropics.

\section{INTRODUCTION}

The neotropical sect. Pharmacosycea is according to results of molecular studies to be regarded as the sister group of (and basis to) the rest of the genus (Herre et al., 1996; Weiblen, 2000; Jousselin et al., 2003). The section shows, however, very strong morphological affinities to the palaeotropical section Oreosycea. The similarities between the two entities caused Corner (1958) to unite them into a single subgenus Pharmacosycea, and that without hesitation. That decision is supported by Berg (2003a, b). The similarities are not only found in the vegetative structures, but extend to floral structures, including the remarkable position of the interfloral bracts, and to the variation in floral characters in the various groups, such as that of the group of mainly New Caledonian species (Corner, 1970) and the group included in the present study.

\section{Section PHARMACOSYCEA}

Most of the species of this section are terrestrial trees which in some species may reach considerable heights, up to $50 \mathrm{~m}$ or more. There is one peculiar exception, described for (and possibly confined to) Ficus crassiuscula, that starts as a root climber on the bases of tree trunks and produces close to the soil a (hemi-epiphytic) tree (Daniels \& Lawton, 1991). The leaves of the juvenile and adult stage are different. In the leaf dimorphy and the initial habit, it resembles species of the Old World subgen. Synoecia (see Berg, 2003c).

The syconia contain numerous staminate flowers with two stamens with large anthers. The pedicels mostly bear (interfloral) bracts, but not such that they become part of the perianth as in some species of sect. Oreosycea (Berg, 1986; Berg \& Wiebes, 1992: 88). 
The species of sect. Pharmacosycea are more generally than in other groups of Ficus difficult to distinguish because of weakness of differentiating characters, possibly due to hybridisation, which is apparently not confined to species of the same subsection, but may also exceed the boundary between the two subsections.

\section{SUBDIVISION}

A subdivision of sect. Pharmacosycea into subsect. Bergianae and subsect. Petenenses has been proposed by Carvajal \& Shabes (1998). It was based on the study of ten species and on characters of the petiole, as exfoliation of the epidermis, the shape in cross section, and the position of the vascular bundles. These differences can be supplemented by tendencies in the variation of the tertiary venation of the lamina and of the length of the stipules. However, the differences found in the figs and flowers are more striking as differentiating characters.

Ficus L. subg. Pharmacosycea (Miq.) Miq. sect. Pharmacosycea (Miq.) Benth. \& Hook.f. subsect. Bergianae Carvajal \& Shabes - Fig. 1a

Ficus L. subg. Pharmacosycea (Miq.) Miq. sect. Pharmacosycea (Miq.) Benth. \& Hook.f. subsect. Bergianae Carvajal \& Shabes (1998) 215. - Type: Ficus insipida Willd.

Lamina mostly smooth (scabrous in F. insipida subsp. scabra or often slightly scabrous beneath in F. adhatodifolia); tertiary venation parallel to the lateral veins (with secondary lateral veins hardly distinguishable from the primary ones) to reticulate (towards the margin); epidermis of the petiole persistent; stipules relatively long, in some species longer than $10 \mathrm{~cm}$. Ostiole superficial, the uppermost ostiolar bracts horizontal and (often hardly) interlocking or short(er) and descending leaving a pore (as sometimes in F. adhatodifolia and F. obtusiuscula), lower down, the bracts descending and leaving a (long) slit-shaped tunnel towards the fig cavity. Pistillate flowers mostly with one stigma, or if two, then usually very different in length or very short, stigmas of adjacent (sessile to pedicellate) long-styled flowers often cohering, sometimes also with those of short-styled flowers, stigmas of adjacent short-styled flowers sometimes cohering, or the majority of the stigmas cohering; the stigmas not clearly in different layers at anthesis. The apices of the (still closed) staminate flowers, the apices of interfloral

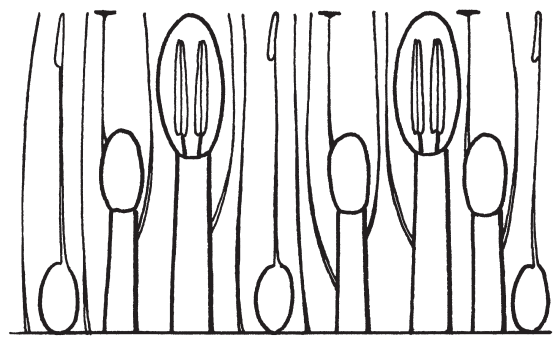

a

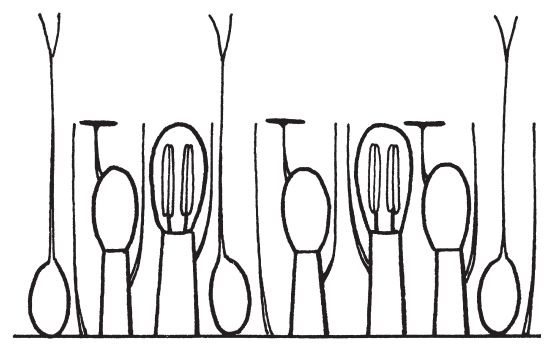

$\mathrm{b}$

Fig. 1. Schematical arrangement of flowers and stigmata in the two subsections of sect. Pharmacosycea: a. subsect. Bergianae, b. subsect. Petenenses. 
bracts and (all) the stigmas for a more or less continuous layer bordering the fig cavity at anthesis.

The subsection comprises the following species: F. adhatodifolia Schott, F. carchiana C.C. Berg, F. crassiuscula Standl., F. gigantosyce Dugand, F. insipida Willd. (subsp. insipida and subsp. scabra C.C. Berg), F. lapathifolia (Liebm.) Miq., F. mutisii Dugand, F. oapana C.C. Berg (spec. nov.? ined.), F. obtusiuscula (Miq.) Miq., F. piresiana Vázq. Avila \& C.C. Berg, F. rieberiana C.C. Berg, and F. yoponensis Desv.

Ficus L. subg. Pharmacosycea (Miq.) Miq. sect. Pharmacosycea (Miq.) Benth. \& Hook.f. subsect. Petenenses Carvajal \& Shabes - Fig. 1b

Ficus L. subg. Pharmacosycea (Miq.) Miq. sect. Pharmacosycea (Miq.) Benth. \& Hook.f. subsect. Petenenses Carvajal \& Shabes (1998) 215. - Type: Ficus apollinaris Dugand (=F. petenensis Lundell).

Lamina in some species often scabrous above and/or beneath; tertiary venation varies from scalariform to reticulate or to largely parallel to the lateral veins (in F. pulchella); epidermis of the petiole flaking off; stipules relatively short. Ostiole often at the bottom of a cavity or tunnel in the apex of the receptacle; several layers of upper ostiolar bracts horizontal and interlocking, those lower down in the ostiolar tunnel descending but not leaving a clear (at most a short) slit-shaped entrance towards the fig cavity. Pistillate flowers with two or one stigma(s), those of the (always pedicellate) short-styled flowers spreading and relatively short and thick, those of the (usually sessile) long-styled flowers erect, longer and slender; the stigmas of long-styled and short-styled flowers clearly arranged in different layers at anthesis, mostly remaining free. The apices of the (still closed) staminate flowers at anthesis at the same level as the apices of the interfloral bracts and the stigmas of the short-styled flowers.

This subsection comprises the following species: $F$. apollinaris Dugand (= F. petenensis Lundell), F. ecuadorensis C.C. Berg (spec. nov. ined.), F. guajavoides Lundell, F. lacunata Kvitvik, F. loxensis C.C. Berg (spec. nov. ined.), F. macbridei Standl., F. maxima Mill., F. maximoides C.C. Berg (spec. nov. ined.), F. pulchella Schott, and F. tonduzii Standl.

\section{ADDITIONAL OBSERVATIONS}

The ranges of distribution of the two subsections largely coincide. The species of subsect. Petenenses are predominantly elements of humid lowland or lower montane forest. The montane element is more pronouncedly represented in subsect. Bergianae; moreover, some of its species occur outside humid forest. A clear link between the differentiating characters of the subsections and habitats is absent.

The amount of pollen produced in syconia of sect. Pharmacosycea is enormous due to the large number of staminate flowers and their large anthers. It is probably much more than needed for passive pollination (see Jousselin \& Kjellberg, 2001). The excess of staminate flowers could be explained by their function to create by the apices of the closed perianths (together with stigmas and apices of interfloral bracts and tepals) a continuous surface for oviposition (and pollination). 
Numerical analyses of the variation in the number of the three types of flowers per syconium and seed-setting in the pistillate flowers may provide indications about the effects of the morphological differences described and reproduction.

It would be of interest to figure out whether the differences described can be linked to morphological features and behaviour of the Tetrapus wasps, associated with the two subsections.

The dimorphy of the pistillate flowers, as with regard to styles and stigmas (see Fig. 1b), distinguishes subsect. Petenenses from any other group of monoecious species which are characterised by stigmas that are similar and arranged at the same level in the syconium and in the more or less variable length of the styles. The dimorphy resembles that known of dioecious species and is a case of floral dimorphism hitherto not recorded in monoecious figs (cf. Cook \& Rasplus, 2003).

Imperfect heterostyly and the ability of all pistillate flowers to produce seeds is logically linked to monoecy in the genus. It is, therefore, very surprising to encounter perfect heterostyly in a group of monoecious species. It is not yet clear whether seed production in short-styled flowers of Petenenses species is affected by the heterostyly found.

The effects of the differences between the flowers at anthesis obliterate more or less in the development towards the fruiting state. This partly explains the features of figure 1 in the paper by Jousselin \& Kjellberg (2004) dealing with pollination in Ficus maxima. The illustration presents a general picture of a monoecious fig rather than that of the actual species at anthesis.

The cavity or tunnel formed in the apex of the receptacle is found in several species of subsect. Petenenses, in some species ( $F$. guajavoides and $F$. lacunata) always, in others (F. loxensis and F. tonduzii) in most or some specimens, or in F. pulchella rarely. The cavity or tunnel can be up to $12 \mathrm{~mm}$ deep, and thus the ostiole so far removed from the fig apex. Dead wasps are often found at such ostioles.

The construction of the ostiole in subsect. Petenenses with several layers of patent and interlocking bracts resembles the situation in the subg. Urostigma sections Americana and Urostigma (p.p. maj.) and several groups of dioecious figs.

The stigmata are in contrast to species of subsect. Bergianae, mostly free in the species of sect. Petenenses, but stigmata/stigmatic arms of neighbouring flowers were once encountered to be cohering in F. apollinaris.

In syconia of species of subsect. Bergianae at anthesis, apices of the still closed staminate flowers, apices of tepals and interfloral bracts, and (free or partly cohering) stigmas border the central cavity of the fig (see Fig. 1a). The interior of the syconium largely resembles that common in subg. Urostigma, but with as clear difference that the staminate flowers remain under the synstigmatic surface at anthesis in subg. Urostigma.

In subsect. Bergianae, the ostiole is never sunken into the apex of the receptacle. Only the uppermost ostiolar bracts are patent and interlocking, the others are descending, which creates a situation rather similar to that in subg. Urostigma sect. Galoglychia and subsect. Malvanthera, in which all ostiolar bracts are descending, leaving a slit-shaped tunnel towards the fig cavity. In F. adhatodifolia and F. obtusiuscula, the upper ostiolar bracts can be so short that they do not interlock, thus leaving a pore-like entrance, similar to the open ostioles of some species of subg. Urostigma subsect. Conosycea (in Asia). 


\section{ACKNOWLEDGEMENT}

Hendrieke Berg (Voss) prepared the drawing.

\section{REFERENCES}

Berg, C.C. 1986. The Ficus species (Moraceae) of Madagascar and the Comoro Islands. Bull. Mus. Natl. Hist. Nat., B, Adansonia 8: 17-55.

Berg, C.C. 2003a. Flora Malesiana precursor for the treatment of Moraceae 1: the main subdivisions of Ficus: the subgenera. Blumea 48: 168-178.

Berg, C.C. 2003b. Flora Malesiana precursor for the treatment of Moraceae 2: Ficus subgenus Pharmacosycea section Oreosycea. Blumea 48: 289-301.

Berg, C.C. 2003c. Flora Malesiana precursor for the treatment of Moraceae 4: Ficus subgenus Synoecia. Blumea 48: 551-571.

Berg, C.C. \& J.T. Wiebes. 1992. African fig trees and fig wasps. Verh. Kon. Ned. Akad. Wetensch., Afd. Natuurk., Tweede Sect. 89: 1-298.

Carvajal, S. \& L.K. Shabes. 1998. Two new subsections of American species of the genus Ficus L. (Moraceae) subgenus Pharmacosycea Miq. sect. Pharmacosycea. Bol. Inst. Bot. Univ. Guadalajara 6: $213-217$.

Cook, J.M. \& J.-Y. Rasplus. 2003. Mutualists with attitude: coevolving fig wasps and figs. Trends Ecol. Evol. 18: 241-248.

Corner, E.J.H. 1958. An introduction to the distribution of Ficus. Reinwardtia 4: 325-355 ('15$\left.45^{\prime}\right)$.

Corner, E.J.H. 1970. Ficus subg. Pharmacosycea with reference to the species of New Caledonia. Philos. Trans., Ser. B. 259: 383-433.

Daniels, J.D. \& R.O. Lawton. 1991. Habitat and host preferences of Ficus crassiuscula, a neotropical strangling fig of the lower-montane forest. J. Ecol. 79: 129-141.

Herre, E.A., C.A. Machado, E. Bermingham, J.D. Nason, D.M. Windsor, S.S. McCafferty, W. van Houten \& K. Bachmann. 1996. Molecular phylogenies of figs and their pollinator wasps. J. Biogeogr. 23: 521-530.

Jousselin, E. \& F. Kjellberg. 2001. The functional implications of active and passive pollination in dioecious figs. Ecol. Letters 4: 151-158.

Jousselin, E. \& F. Kjellberg. 2004. Flowers specialization in a passively pollinated monoecious fig: a question of style and stigma? Int. J. Pl. Sci. 165: 587-593.

Jousselin, E., J.-Y. Rasplus \& F. Kjellberg. 2003. Convergence and coevolution in a mutualism: evidence from a molecular phylogeny of Ficus. Evolution 57: 1255-1269.

Weiblen, G.D. 2000. Phylogenetic relationships of functionally dioecious Ficus (Moraceae) based on ribosomal DNA sequences and morphology. Amer. J. Bot. 87: 1342-1357. 